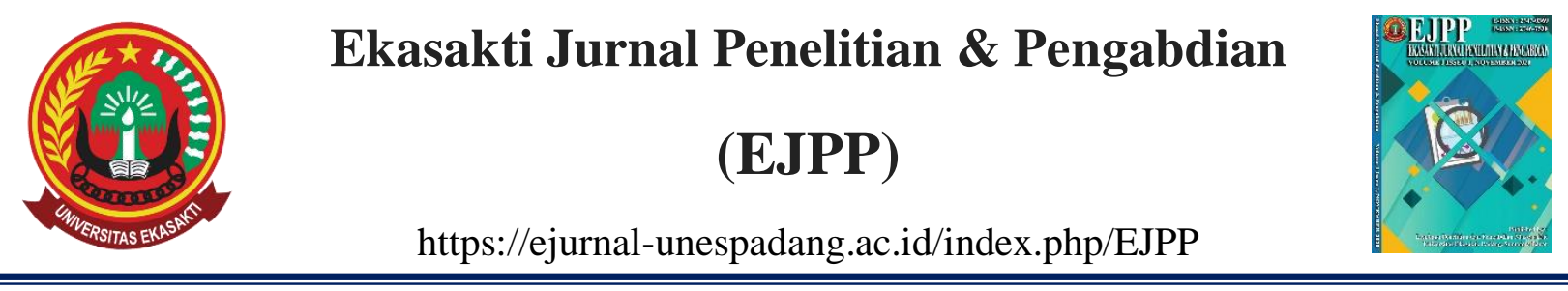

\title{
PELATIHAN PENINGKATAN KOMPETENSI TENAGA ADMINISTRASI SMK NEGERI KOTA PADANG
}

\author{
Susi Yuliastanty ${ }^{1}$, dan Hazlif Nazif ${ }^{2}$ \\ 1) Fakultas Ekonomi Universitas Ekasakti \\ Email: susysylqu@gmail.com \\ ${ }^{2)}$ Fakultas Teknik Universitas Ekasakti \\ Email: hazlif_n@yahoo.co.id
}

\section{INFO ARTIKEL}

Received : 20/10/2021

Revised : :30/10/2021

Publish : 08/11/2021

Kata Kunci:

Kompetensi, Pelatihan, SMK, Tenaga

Administrasi.

\begin{abstract}
ABSTRAK
Di balik keberaturan tata kelola sekolah yang menghasilkan efektivitas penyelenggaraan pendidikan dan pembelajara selalu ada Tenaga Administrasi Sekolah (TAS) yang bekerja dengan professional. Begitu pentingnya keberadaan TAS sehingga kualifikasi dan kompetensinya di atur melalui peraturan pemerintah (Permendiknas nomor 24 tahun 2008). Berbeda dengan guru, urgensi ruang lingkup kerja TAS dianggap masih berada di bawah tugas-tugas guru. Maka perhatian terhadap peningkatan kompetensi dan profesionalitas TAS baik dari pusat, pemerintah daerah, maupun pada unit terbawah yaitu sekolah masih sangat kurang. Pelatihan ini bertujuan untuk meningkatkan kompetensi TAS khususnya di SMK dalam mengelola, mengembangkan, dan memberikan layanan berbasis mutu di sekolah. Kegiatan ini juga dimaksudkan untuk memberikan pelatihan kepada TAS dalam melaksanakan layanan administrasi sekolah di masa pandemic COVID-19. Pelatihan ini mengadaptasi protocol kesehatan selama pandemic COVID-19 sehingga dilaksanakan secara daring menggunakan layanan zoom cloud meeting. Pelatihan ini terdiri dari dua segmentasi: (1) penyampaian materi dengan akumulasi 20 jam pelajaran dan (2) penugasan terbimbing dengan akumulasi 12 jam pelajaran. Efektivitas pelatihan diukur dari tanggapan peserta pelatihan terhadap angket efektivitas pelatihan dan penilaian pada hasil kerja peserta pada segmen penugasan terbimbing. Hasil evaluasi akhir dapat disimpulkan terdapatnya peningkatan pemahaman, keterampilan, dan produktivitas TAS dalam melaksanakan tugas masa pandemic COVID-19.
\end{abstract}

\section{ABSTRACT}

Keywords:

Competence, Training, Vocational High School, Administrative Personnel.
Behind the regularity of school governance that results in the effectiveness of education and learning, there is always a School Administration Personnel (TAS) who works professionally. The existence of TAS is so important that its qualifications and competencies are regulated through government regulations (Permendiknas number 24 of 2008). In contrast to teachers, the urgency of the scope of work of TAS is still considered to be under the duties of the teacher. So the attention to increasing the competence and professionalism of TAS both from the center, local government, and at the lowest unit, namely schools, is still very 
lacking. This training aims to improve the competence of TAS, especially in Vocational Schools in managing, developing, and providing quality-based services in schools. This activity is also intended to provide training to TAS in carrying out school administration services during the covid-19 pandemic. This training adapts health protocols during the covid-19 pandemic so that it is carried out online using the Zoom cloud meeting service. This training consists of two segments: (1) delivery of material with an accumulation of 20 hours of lessons and (2) guided assignments with an accumulation of 12 hours of lessons. The effectiveness of the training is measured by the responses of the trainees to the questionnaire on the effectiveness of the training and the assessment of the work results of the participants in the guided assignment segment. The results of the final evaluation can be concluded that there is an increase in TAS understanding, skills, and productivity in carrying out tasks during the COVID19 pandemic.

DOI: https://doi.org/10.31933/ejpp.v2i1.414

\section{PENDAHULUAN}

Tenaga Administrasi Sekolah (TAS) memiliki peran yang tak kalah penting dengan guru. Ruang lingkup kerja TAS ibarat dapur produksi yang mengolah berbagai sumber daya yang dimiliki sekolah untuk mencapai tujuan pendidikan dan pembelajaran. Ruang lingkup kerja TAS meliputi semua aspek pengelolaan pendidikan di sekolah: peserta didik, kurikulum, sarana dan prasarana, kepegawaian, keuangan, layanan khusus, hubungan sekolah-masyarakat, serta pengelolaan lingkungan dan budaya sekolah (Ditjen GTK, 2019). Di balik keberaturan tata kelola sekolah yang menghasilkan efektivitas penyelenggaraan pendidikan dan pembelajara selalu ada TAS yang bekerja dengan professional. Begitu pentingnya keberadaan TAS sehingga kualifikasi dan kompetensinya di atur melalui peraturan pemerintah (Permendiknas nomor 24 tahun 2008). Sama halnya dengan guru, dalam melaksanakan tugas TAS dituntut untuk menguasai empat kompetensi: kompetensi kepribadian, kompetensi sosial, kompetensi teknis, dan kompetensi manajerial. Penguasaan terhadap empat kompetensi ini diharapkan dapat membekali TAS melaksanakan tugas-tugasnya dengan produktif dan professional.

Berbeda dengan guru, urgensi kerja TAS dianggap masih berada di bawah tugas-tugas guru. Maka perhatian terhadap peningkatan kompetensi dan profesionalitas TAS baik dari pusat, pemerintah daerah, maupun pada unit terbawah yaitu sekolah masih sangat kurang. Padahal layaknya tenaga pendidik atu guru, TAS juga membutuhkan pembinaan dalam melaksanakan tugas. Wawancara dengan salah seorang pengawas SMK Kota Padang menyebutkan "pelatihanpelatihan bagi TAS memang sangat kurang, apalagi di tengah-tengah pergantian kurikulum dan kebijakan-kebijakan baru terkait pembelajaran saat ini sehingga yang selalu menjadi sasaran dari sosialisasi meupun pelatihan adalah guru. Begitu juga dengan program diknas provinsi yang masih focus pada peningkatan kompetensi guru (wawancara, 23/05/2020)." Wawancara lebih lanjut dengan salah seorang kepala SMK kota Padang menyebutkan "bentuk-bentuk pelatihan bagi TAS, TU, maupun operator memang jarang dan kalaupun ada lebih pada pengenalan penggunaan aplikasi-aplikasi baru keadministrasian sekolah seperti dapodik, rapor elektronik, dan SIM sekolah." Berdasarkan wawancara di atas dapat disimpulkan bahawa pelatihan-pelatihan TAS 
yang sering diberikan pemerintah hanya pada tataran kompetensi teknis TAS. Sehingga sudah tentu yang ditunjuk sekolah untuk mengikuti pelatiha-pelatihan tersebut hanya operator sekolah. Padahal tim TAS dan bidang tugasnya lebih luas dan terkait juga dengan tuntutan kompetensi TAS yang di amanatkan Permendiknas nomor 24 tahun 2008.

Akibat dari minimnya pembinaan kompetensi yang diberikan kepada TAS berdampak pada efektivitas dan produktivitas kerja TAS bahkan pada skala yang lebih besar, kompetensi TAS dapat mempengaruhi mutu dan eksistensi sekolah (Ushansyah, 2017). Maka tidak jarang jika teori dan hasil-hasil penelitian menunjukkan berbagai keberhasilan sekolah ditentukan pada pengelolaan di tataran manajemen sekolah untuk menyediakan layanan pendidikan yang bermutu (Amanchukwu, Stanley, \& Ololube, 2015; Blau \& Presser, 2013;Center, 2012;Bellei, Vanni, Valenzuela, \& Contreras, 2016; Cheng, 1996). Hasil tes sederhana yang kami lakukan untuk mengukur tingkat pengetahuan TAS SMK Kota Padang terkait pelaksanaan bidang tugasnya menunjukkan nilai yang sangat memprihatinkan. Dari 26 soal yang diberikan, nilai maksimal yang mampu dicapai TAS hanya 15 poin yang diperoleh 3 orang dari 38 orang TAS yang mengikuti tes. Dapat disimpulkan tingkat capaian responden (TCR) pada tes ini hanya 38.26\%. Pada Gambar 1 disajikan sebaran skor yang diperoleh TAS.

Minimnya pengangkatan TAS oleh pemerintah, memaksa kepala sekolah memberdayakan guru melakukan tugas-tugas TAS bahkan mengangkatnya menjadi kepala TAS. Kasus ini ternyata menimbulkan masalah lainnya. Wawancara dengan TAS SMK Kota Padang juga terungkap bahwa TAS merasa tidak memiliki kejelasan secara structural maupun penghargaan atas jabatan TAS yang diembannya. Di sisi lain TAS juga mengakui bahwa kompetensi yang dimilikinya tidak cukup dalam mengelola layanan administrasi dan pengembangan sekolah karena latar belakangnya adalah guru (wawancara, 23/05/2020). Kasus ini tentu semakin buruk jika pembinaan dan pelatihan kepada TAS juga minim. Apalagi dalam menghadapi pandemic covid-19 TAS merupakan garda terdepan yang bertugas mengkondisikan aktivitas sekolah agar tetap beroperasi sesuai dengan SOP/protocol kesehatan adaptasi new normal. Maka sudah tentu pelatihan TAS menjadi urgensi yang perlu segera dilakukan.

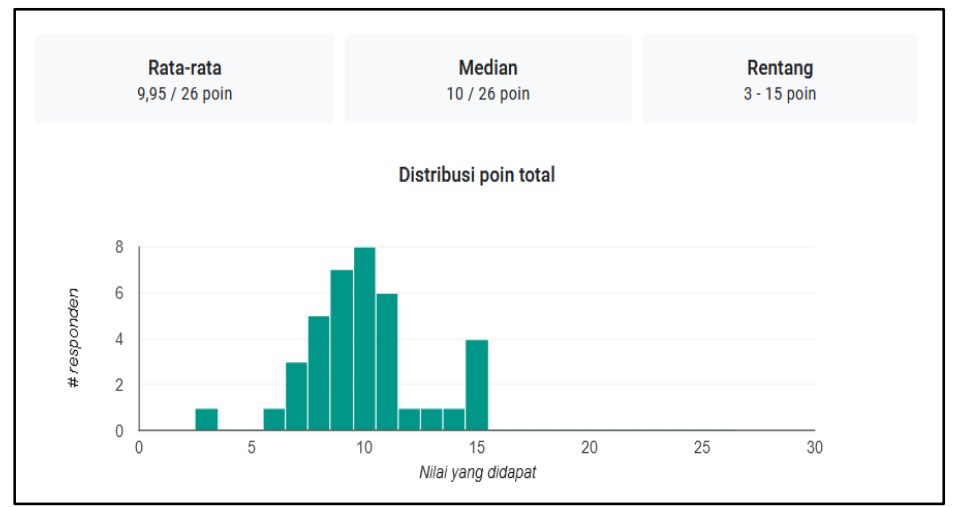

Gambar 1. Bagan Sebaran Skor Tes TAS SMK Kota Padang

Kota Padang adalah Kota terbesar di pantai barat Pulau Sumatra dan ibu kota dari provinsi Sumatra Barat, Indonesia. Kota ini merupakan pintu gerbang barat Indonesia 
dari Samudra Hindia. Wilayah administratifnya memiliki luas $694,96 \mathrm{~km}^{2}$ dengan kondisi geografi berbatasan laut dan dikelilingi perbukitan dengan ketinggian mencapai 1.853 mdpl. Kota Padang sejak dari zaman kolonial Belanda telah menjadi pusat pendidikan di Sumatra Barat. Tercatat pada tahun 1864, jumlah pelajar yang terdaftar di sekolah yang ada di kota ini sebanyak 237 orang. Jumlah SMK kota Padang saat ini baik negeri maupun Swasta sebanyak 42 buah.

Potensi sumber daya tenaga administrasi sekolah itu perlu terus bertumbuh dan berkembang agar dapat melakukan fungsinya secara potensial Namun demikian, sampai saat sekarang ini, semua kompetensi belum sepenuhnya dikuasai oleh tenaga administrasi sekolah, karena tingkat ketersediaan fasilitas dan tenaga SDM yang mendukung dalam memberikan pembinaan masih relatif kurang. Oleh sebab itu banyak tenaga administrasi sekolah khususnya SMK bergabung dalam beberapa kelompok kegiatan untuk menambah pengetahuan dan keterampilan, namun mereka masih rendah pengetahuan dan keterampilan dalam melaksanakan tugas-tugas sesuai dengan tugas Masing-Masing. Untuk itu perlu meningkatkan pengetahuan dan keterampilan mereka khususnya dalam bidang administrasi perlu diberikan pembinaan khusus sehingga tenaga administrasi sekolah di SMK betul-betul memahami peran penting yang harus mereka lakukan di dalam tugas di sekolah.

\section{METODE PENELITIAN}

\section{Tahapan Pelaksanaan Kegiatan dan Metode yang Digunakan}

Untuk melaksanakan kegiatan pelatihan dapat dipakai berbagai metode sesuai dengan sasaran yang akan dicapai, agar dalam pemberian materi dapat diserap oleh peserta dengan mudah. Untuk lebih jelas maka berikut ini akan dibahas metode yang akan digunakan sesuai sasaran dalam pelatihan:

1. Metode ceramah, digunakan untuk memperkenalkan pengetahuan dan keterampilan yang diberikan. Metode ceramah diberikan ketika menyampaiakan materi kompetensi tenaga administrasi sekolah, sebagai pengayaan dan pemahaman tentang tugas dan fungsi dalam melaksanakan tugas sebagai tenaga administrasi sekolah.

2. Metode diskusi dan tanya jawab, diberikan untuk meningkatkan pemahaman peserta terkait materi-materi pelatihan yang telah diberikan baik secara teoritis maupun implementasi praktisnya dilapangan. Selanjutnya dilakukan tanya jawab tentang materi apa yang diterangkan. Tanya jawab juga berfungsi untuk mengetahui sejauh mana pemahaman peserta terhadap materi yang diberikan.

3. Metode latihan/ studi kasus tentang layanan administrasi sekolah digunakan untuk pembentukan keterampilan analisis dan pemecahan masalah tenaga administrasi sekolah dalam menghadapi kasus-kasus actual selama melaksanakan tugas administrasi di sekolah.

4. Latihan penyusunan dan implementasi SOP/protocol kesehatan layanan admninistrasi sekolah, diberikan untuk memberikan keterampilan kepada TAS SMK dalam 
menyusun perangkat administrasi dalam bentuk SOP dan bekerja berdasarkan SOP yang telah ditetapkan.

\section{Partisipasi Mitra}

Partisipasi mitra dalam kegiatan ini adalah memberikan izin pelaksanaan kegiatan pengabdian, menugaskan, dan mengkoordinir peserta selama tahapan kegiatan pelatihan peningkatan kompetensi TAS SMK dilaksanakan.

\section{Evaluasi}

Evaluasi dilakukan dilakukan melalui du acara: (1) pengamatan, dilakukan untuk melihat tingkat antusias atau keseriusan peserta selama melaksanakan pelatihan. Hasil pengamatan menunjukkan tingginya antusuas dan keseriusan TAS selama melaksanakan pelatihan yang dibuktikan dengan kehadiran TAS secara fulltime di forum virtual. (2) angket, diberikan untuk meminta informasi dari peserta terkait dengan efektivitas pelatihan yang telah dilakukan, dan (3) penilaian terhadap SOP layanan administrasi sekolah masa pandemic covid-19 yang telah disusun TAS pada segment penugasan terbimbing.

\section{HASIL DAN PEMBAHASAN}

\section{Deskripsi Kegiatan PkM}

Kegiatan yang dilakukan dalam pengabdian kepada masyarakat ini adalah Pelatihan Peningkatan Kompetensi Tenaga Administrasi Sekolah (TAS) SMK Kota Padang. Penyajian materi dalam kegiatan ini dimulai dari: (1) konsep dasar dan ruang lingkup tugas TAS SMK, (2) pelayanan prima TAS SMK, (3) kompetensi teknis dan manajerial TAS SMK, (4) komunikasi efektif dan implementasinya dalam pelayanan pendidikan di sekolah (5) pemanfaatan IT dalam menunjang efektivitas pelaksanaan tugas TAS, dan (6) pembinaan kompetensi TAS masa pandemi covid-19. Gambaran pelaksanaan IPTEK yang telah ditransfer kepada mitra adalah sebagai berikut.

\section{Konsep Dasar dan Ruang Lingkup Tugas TAS SMK}

Konsep dasar dan ruang lingkup tugas TAS disampaikan oleh Prof. Dr. Sufyarma Marsidin, M.Pd. Materi ini disajikan di awal dalam rangka memperkuat pengetahuan dan pemahaman tenaga TAS SMK terkait dengan kompetensi dan bidang-bidang tugasnya di sekolah. Sebelum memulai pemaparan materinya, pemateri mencoba mengukur tingkat pemahaman peserta pelatihan dengan melontarkan beberapa pertanyaan dasar terkait dengan implementasi 4 kompetensi TAS di sekolah. Dari pertanyaan yang dilontarkan pemateri tidak banyak peserta yang mampu menjawab dengan baik. Dari jawaban yang diberikan peserta, sesekali pemateri mencoba memperbaiki konsep yang selama ini dipegang oleh peserta pelatihan. Kompetensi TAS diatur dalam Permendiknas nomor 24 Tahun 2008. Permendiknas mengelompokkan TAS menjadi tiga, yaitu kepala TAS, Pelaksana urusan, dan petugas layanan khusus. Kepala TAS wajib menguasai empat kompetensi dasar yaitu kompetensi kepribadian, sosial, teknis, dan manajerial. Sementara pelaksana urusan 
dan petugas layanan khusus wajib menguasai tiga kompetensi dasar yaitu kepribadian, sosial, dan teknis (Permendikbud, 2008). Secar umum pemahaman TAS hanya terkai dengan pelaksanan pekerjaan teknisnya saja. Dengan keempat kompetensi tersebut TAS dituntut melaksanakan tugasnya pada tataran manajemen sekolah. Secara umum khususnya kepala TAS membantu pelaksanaan tugas manajerial kepala sekolah. Dengan demikian bidang ruang lingkup tugas TAS mencakup semua semua aspek pengelolaan sekolah terutama terkait dengan 8 Standar Nasional Pendidikan.

Materi ini disampaikan dengan menggunakan metode ceramah dan diselingi dengan tanya jawab. Pola penyajian materi tersebut kelihatannya menarik bagi peserta. Hal ini dapat dilihat dari tingginya motivasi mereka mengikuti penyajian materi tersebut. Peserta mengikutinya dengan serius dan tidak ada peserta yang keluar masuk ruangan conference virtual. Selain itu, tingginya motivasi dan semangat peserta mengikuti kegiatan ini dapat dilihat dari pertanyaan dan diskusi yang berkembang. Ini juga merupakan salah satu indikasi bahwa peserta dapat memahami materi yang disampaikan dengan baik.

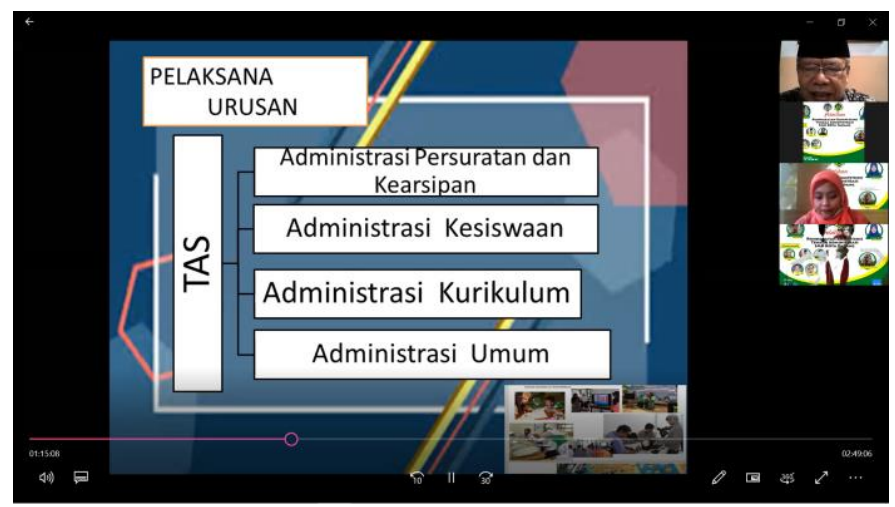

Gambar 2. Penyampaian Materi: Konsep Dasar dan Ruang Lingkup TAS

\section{Pelayanan Prima Tenaga Administrasi SMK}

Materi pelayanan prima TAS SMK disampaikan oleh Dr. Rifma, M.Pd. Penyajian materi dimulai dengan kasus-kasus pelayanan administrasi di sekolah. Pendekatan ini dipilih pemateri untuk menarik perhatian peserta. Terbukti tampak lebih antusias dan tertantang dengan pernyataan sindiran yang sesekali disampaikan penyaji. Pendekatan ini ternyata mampu membuat peserta dan suasana ruang pelatihan virtual lebih hidup. Selanjutnya pemateri memulai menyampaikan konsep-konsep layanan prima di sekolah. Penyampaian materi ini masih diselingi dengan contoh-contoh praktis dan kasus-kasus layanan pendidikan yang dilakukan TAS di sekolah. Layanan prima merupakan implementasi kompetensi sosial dan keperibadian TAS dalam memberikan layanan administrasi pendidikan secara optimal dan memuaskan. Sebagai bagian dari tim manajemen sekolah, TAS bertanggung jawab melaksanakan dan memastikan setiap pelanggan internal (misalnya peserta didik dan guru) dan eksternal (misalnya orang tua, stakeholder) memperoleh layanan yang dibutuhkannya. Konsep quality 
service atau quality excellence ini dapat dibawa pada organisasi nonprofit seperti sekolah karena sejatinya prinsip penyelenggaraan sekolah juga merupakan sebuah service/layanan pendidikan (Faujiah, 2018; Ibrahim, 2014; Nurlia, 2018; Tjiptono, 2004;Samsirin, 2015).

Penyaji menekankan materi layanan prima kepada sikap kerja yang harus ditampilkan dan kuasai TAS. Berbagai kasus ketidakpuasan peserta didik dan orang tua/masyarakat terhadap sikap TAS diangkat sebagai pembahasan kontekstual (Shaylide, 2014;Kartiwi \& Sa'ud, 2015; Liana, 2016). Dalam penyajian materi kedua ini, peserta juga kelihatannya sangat antusias. Salah satu indikasi dari keseriusan peserta mengikuti penyajian materi ini adalah banyaknya pertanyaan dan permasalahanpermasalan yang diajukan oleh peserta. Tanya jawab yang terjadi juga menunjukkan rasa keiingintahuan peserta yang tinggi, karena pembahasan yang di sajikan pemateri bersifat aplikatif sehingga peserta mudah memahaminya.

\section{Kompetensi Teknis Dan Manajerial TAS SMK}

Materi kompetensi teknis dan manajerial TAS SMK disampaikan oleh Prof. Dr. Rusdinal, M.Pd. Narasumber memulai presentasinya dengan menayangkan video animasi yang mengandung nilai-nilai kerja yang harus dimiliki TAS sebagai bagaian dari tim manajemen sekolah. Pendekatan yang dilakukan pemateri ternyata ampuh menyegarkan kembali pikiran peserta mengingat jadwal presentasi dilakukan pada jam-jam kritis (siang hari). Peserta juga tambak antusias ketika pemateri meminta peserta merespon video yang telah ditayangkan. Peserta diminta mengidentifikasi nilai-nilai apa saja yang tersirat dalam video yang baru saja disaksikannya. Banyak dari peserta menyampaiakan pendapatnya, diantara jawaban peserta adalah: kerjasama, kreativitas, toleransi, skala prioritas, visioner, leadership, koordinasi, dan komando.

Prof. Dr. Rusdinal, M.Pd melanjutkan pemaparan materi kompetensi teknis dan manajerial TAS sesuai dengan Permendiknas Nomor 24 Tahun 2008. Penyampaian materi diawali dengan mengajak TAS untuk memahami tantangan pendidikan saat ini dam masa yang akan datang dan dampaknya terhadap manjemen pendidikan yang menjadi bidang tugasnya di sekolah. pemateri juga menyapaikan Restra kementerian pendidikan dan kebudayaan terhadap target dan sasaran pendidikan khusunya untuk SMK. Berdasarkan hasil pengamatan dapat disimpulkan peserta hikmat mendengarkan paparan dari pemateri. Selajutnya peserta diberi izin menyampaikan pertanyaan maupun keluahannya terhadap praktik-praktik kompetensi teknis dan manajerial sekolah dalam kaitannya dengan tantangan pendidikan di SMK sekarang dan masa akan datang.

4. Komunikasi Efektif dan Implementasinya dalam Pelayanan Pendidikan Di SMK Materi komunikasi efektif dan implementasinya dalam pelayanan pendidikan di SMK disampaikan oleh Dr. Jasrial, M.Pd. Kegiatan ini diawali dengan meng-upgrading 
pesprektif guru terhadap komunikasi efektif yang telah digunakannya selama ini dalam memberikan layanan pendidikan si sekolah. Selanjutnya penjelasan materi dilanjutkan dengan konsep dasar komunikasi, dan dilanjutkan dengan teknik-teknik dan indicator keberhasilan komunikasi TAS di sekolah. Komunikasi efektif juga merupakan bagian dari implementasi layanan prima/quality service di sekolah (Nisa, 2016; Rokhmah \& Anggorowati, 2017). keterampilan komunikasi efektif menjadi indicator profesionalitas TAS dalam memberikan layanan berbasis mutu disekolah (Rokhmah \& Anggorowati, 2017;Achmadwati, Meirawan, \& Rahyasih, 2018; Sumarsono, 2015) Penyampaian materi ini dilakukan dengan metode ceramah, dan tanya jawab. Beberapa orang menyampaikan pertanyaan maupun kendala-kendala yang dihadapinya dalam membangun komunikasi efektif untuk memberikan layanan maksimal kepada para stakeholder yang berurusan ke sekolah. Pada tahap inilah diskusi panjang terjadi, peserta tampak antusias dengan memberikan pertanyaan balikan maupun mencoba untuk membagi pengalamannya dalam menjaga hubungan, pemahaman baik stakeholder, dan sistem kerja dengan berkomunikasi efektif. Diskusi antara pemateri dan pserta pelatihan juga menyimpulkan pentingnya membangun SOP dan standar kerja sebagai panduan/arah yang dapat dipedomani TAS dalam menjalankan tugasnnya.

\section{Pemanfaatan IT Dalam Menunjang Efektivitas Pelaksanaan Tugas TAS}

Materi pemanfaatan IT dalam menunjang efektivitas pelaksanaan tugas TAS disampaikan oleh Dr. Darmasyah, ST, M.Pd. Materi ini dipilih dengan tujuan agar TAS memiliki tambahan pengetahuan terkait dengan penggunaan IT yang dapat meningkatan efektivitas pelaksanaan tugasnya. Pemanfaatan IT merupakan ruang lingkup komptensi teknis TAS. Pemberian materi ini dimaksudkan untuk mengupgrade pengetahuan dan keterampilan TAS menggunakan IT dan softwere-softwere yang mendukung efektivitas dan efisiensi pelaksanaan tugas TAS.

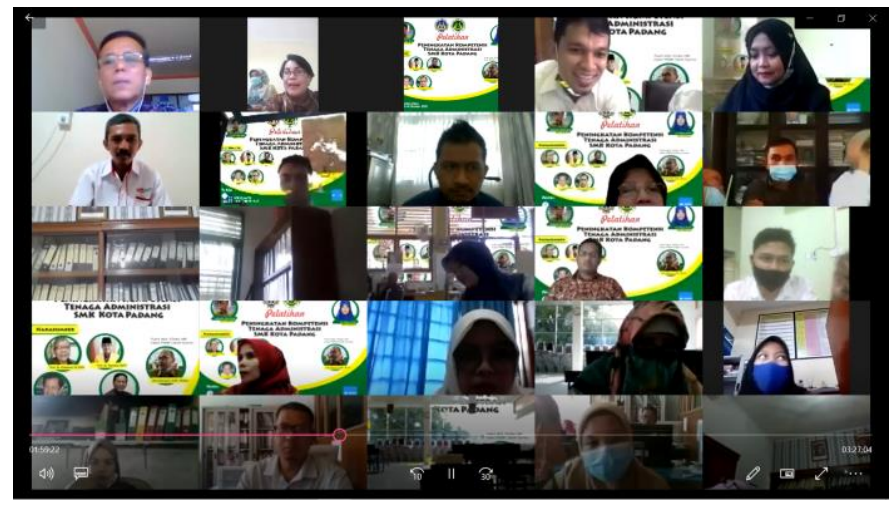

Gambar 3. Penyampaian Materi: Pemanfaatan IT dalam meningkatkan inovasi dan produktivitas sekolah 
Sebelum memulai pemaparan materinya, pemateri mencoba mengukur tingkat pemahaman peserta pelatihan dengan melontarkan beberapa pertanyaan dasar terkait materi tersebut. Dari pertanyaan yang dilontarkan pemateri tidak banyak peserta yang mampu menjawab dengan baik. Materi ini disampaikan dengan menggunakan metode ceramah dan diselingi dengan tanya jawab dan praktek. Materi juga diperkaya dengan mengenalkan aplikasi-aplikasi baru yang dapat digunakan TAS dalam meningkatkan kreativitas dan inovasi dalam melaksanakan tugas baik yang berbayar, maupun gratis.

\section{Pembinaan Kompetensi TAS Masa Pandemi Covid-19}

Materi pembinaan pembinaan kompetensi TAS masa pandemic covid-19 disampaikan oleh salah satu pengawas SMK provinsi Sumatera Barat yaitu bapak Armen, S.Pd, S. Par, M.Si. sebelum memamparkan materinya, pemateri menanyangkan video satu SMK yang sukses beradaptasi dengan situasi new normal selama pandemic covid-19. Peserta tampak antusias menyaksikan. Penyampaian materi dilanjutkan dengan penyelenggaraan tugas-tugas TAS yang harus diadaptasi dengan situasi pandemic covid-19 (P3GTK, 2020). Secara umum materi difokuskan pada penyusunan SOP layanan-layanan administrasi baik secara langsung maupun dengan elektronik/IT berbasis internet. Karena juga berperan sebagai pengawas SMK, pemateri mencoba untuk meyakinkan dan menugaskan peserta untuk melengkapi/menyusun SOP layanan-layanan administrasi yang belum tersedia di sekolah masing-masing. Peserta tampak tenang mendengarkan pemaparan dari pemateri yang juga pengawas sekolah mereka. Diakhir penyampaian materi, beberapa orang peserta menyampaikan pertanyaan dan keluhan-keluhannya dalam melaksanakan tugasnya. Ini menjadi masukkan juga bagi dinas pendidikan provinsi melalui pengawas terhadap TAS khususnya di SMK.

\section{Studi Kasus}

Studi kasus diberikan untuk memberikan penguatan pemahaman dan latihan penyelesaian masalah yang berkaitan dengan pelaksanaan tugas TAS di sekolah khususnya selama pandemi covid-19. semua peserta tampak antusian menyampaikan sudut pandangnya terhadap kasus-kasus yang dilontarkan panitia. Sesi ini berakhir dengan diskusi yang cukup panjang antar panitia, pemateri, dan peserta.

\section{Efektivitas Pelatihan}

Hasil analisis data efektivitas pelatihan oleh peserta pelatihan peningkatan kompetensi TAS SMK Kota Padang disajikan pada gambar 2 di bawah ini. 


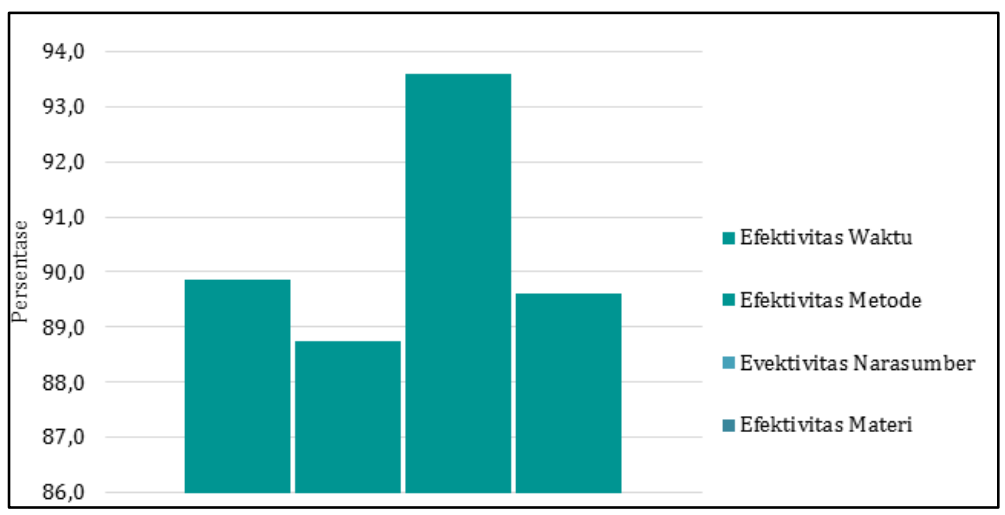

\section{Gambar 4. Bagan Hasil Uji Efektivitas Pelatihan}

Gambar 2 menunjukkan data respon peserta pelatihan/TAS terhadap empat aspek efektivitas pelatihan yaitu efektivitas waktu, metode, narasumber, dan materi. Akumulasi rata-rata respon peserta pelatihan/TAS terhadap efektivitas model mencapai 90,4\%. Berdasarkan data pada gambar 2 di atas tingkat efektivitas waktu berdasarkan respon peserta pelatihan/TAS mencapai $89,9 \%$, untuk efektivitas metode mencapai $88,7 \%$, efektivitas narasumber mencapai 93,6\%, dan efektivitas materi mencapai 89,6\%. Dapat disimpulkan bahwa pelatihan peningkatan kompetensi TAS SMK Kota Padang yang dilaksanakan oleh tim Program Pengabdian kepada Masyarakat (PkM) Universitas Negeri Padang tahun 2020 “efektif”. Keahlian dan kompetensi narasumber menjadi aspek tertinggi dalam menunjang efektivitas pelaksanaan pelatihan ini. Disamping itu keseriusan peserta selama melaksanakan pelatihan baik pada segmentasi penyampaian materi/pelatihan virtual maupun penugasan terbimbing juga menjadi indicator keberhasilan pelatihan ini.

\section{KESIMPULAN}

\section{Simpulan}

Administrasi SMK Kota Padang” telah dilaksanakan secara virtual dengan menggunakan aplikasi Zoom Cloud Meeting selama 2 hari pada 13 s.d 14 Oktober 2020 mulai pukul 08.00-15.00 wib. Khalayak sasaran pada kegiatan ini adalah TAS SMK Negeri Kota Padang yang terdiri dari: (1) kepala TAS, (2) Pelaksana urusan, dan (3) petugas layanan khusus. Penugasan terbimbing dilaksanakan dalam jangka waktu 2 minggu setelah dilaksanakannya pelatihan. Selama pelaksanaan penugasan terbimbing narasumber berkoordinasi dan memberikan bimbingan kepada TAS secara virtual melalui Zoom Cloud Meeting dengan waktu yang kondisional/ditentukan dengan kesepakatan narasumber dan TAS.

Indikator keberhasilan kegiatan ini adalah (1) terjadinya peningkatan pengetahuan, pemahaman, dan keterampilan TAS dalam melaksanakan tugas-tugas teknis dan administratifnya, 
(2) tersusunnya SOP layanan administrasi sekolah masa pandemic covid-19 bagi semua SMK Negeri Kota Padang, dan (3) terimplementasinya SOP yang disusun TAS dalam memberikan layanan administrasi yang efektif dan prima selama masa pandemi covid-19 di sekolah masingmasing. Efektivitas pelatihan diukur dari tanggapan peserta pelatihan terhadap angket efektivitas pelatihan dan penilaian pada hasil kerja peserta pada segmen penugasan terbimbing. Hasi evaluasi akhir dapat disimpulkan terdapatnya peningkatan pemahaman, keterampilan, dan produktivitas TAS dalam melaksanakan tugas masa pandemic covid-19.

\section{Saran}

Berdasarkan kesimpulan di atas dapat dikemukakan beberapa saran sebagai berikut:

1. Diharapkan pelatihan seperti ini dapat dilanjutkan kembali, tetapi dengan peserta yang belum mempunyai kesempatan untuk ikut pada kegiatan ini.

2. Semua pihak, Lembaga Pengabdian Kepada Masyarakat Universitas Negeri Padang, Dinas Pendidikan Kota Padang, UPT Dinas Pendidikan Kota Padang kiranya dapat memantau pelaksanaan hasil pelatihan ini, sehingga kompetensi TAS dalam melaksanakan tugasnya dapat ditingkatkan secara berkelanjutan.

3. Perlu dilanjutkan pelatihan-pelatihan lain yang relevan, baik atas permintaan pihak sekolah sendiri maupun dari pihak Universitas Negeri Padang.

\section{REFERENSI}

Achmadwati, W., Meirawan, D., \& Rahyasih, Y. (2018). Pemanfaatan Sarana Prasarana Kerja, Self Capacity Building, Dan Kinerja Tenaga Administrasi Sekolah. Jurnal Administrasi Pendidikan. Https://Doi.Org/10.17509/Jap.V25i1.11566

Amanchukwu, R. N., Stanley, G. J., \& Ololube, N. P. (2015). A Review Of Leadership Theories, Principles And Styles And Their Relevance To Educational Management. Management.

Bellei, C., Vanni, X., Valenzuela, J. P., \& Contreras, D. (2016). School Improvement Trajectories: An Empirical Typology. School Effectiveness And School Improvement. Https://Doi.Org/10.1080/09243453.2015.1083038

Blau, I., \& Presser, O. (2013). E-Leadership Of School Principals: Increasing School Effectiveness By A School Data Management System. British Journal Of Educational Technology. Https://Doi.Org/10.1111/Bjet.12088

Center, N. H. S. (2012). High School Improvement: Indicators Of Effectiveness And School-Level Benchmarks. National High School Center.

Cheng, Y. C. (1996). A School-Based Management Mechanism For School Effectiveness And Development. School Effectiveness And School Improvement. Https://Doi.Org/10.1080/0924345960070102

Ditjen Gtk. (2019). Modul Bimbingan Teknis Peningkatan Kompetensi Tenaga Administrasi Sekolah. Kementerian Pendidikan Dan Kebudayaan. 
Educational Leadership And Management: Theory, Policy, And Practice. (2007). South African Journal Of Education.

Faujiah, A. (2018). Service Excellence. Ekosiana: Jurnal Ekonomi Syari'ah. Https://Doi.Org/10.30957/Ekosiana.V4i02.30

Ibrahim, A. (2014). Konsep Dasar Manajemen Perpustakaan Dalam Mewujudkan Mutu Layanan Prima Dengan Sistem Temu Kembali Informasi Berbasis Digital. Desember.

Kartiwi, A., \& Sa’ud, U. (2015). Kualitas Layanan Akademik Sekolah. Jurnal Administrasi Pendidikan Upi. Https://Doi.Org/10.17509/Jap.V22i2.5387

Liana, N. A. (2016). Analisis Faktor Yang Mempengaruhi Kepuasan Orang Tua Peserta Didik Terhadap Layanan Pendidikan. Manajemen Pendidikan.

Nisa, H. (2016). Komunikasi Yang Efektif Dalam Pendidikan Karakter. Universum. Https://Doi.Org/10.30762/Universum.V10i1.223

Nurlia. (2018). Strategi Pelayanan Dengan Konsep Service Excellent. Meraja Journal.

P3GTK. (2020). Tenaga Administrasi Sekolah (Tas) Merupakan Ujung Tombak Pelayanan Di Sekolah. Https://P3gtk.Kemdikbud.Go.Id/Konten/Tenaga-Administrasi-Sekolah-TasMerupakan-Ujung-Tombak-Pelayanan-Di-Sekolah-71eaiptt

Rokhmah, N. A., \& Anggorowati, A. (2017). Komunikasi Efektif Dalam Praktek Kolaborasi Interprofesi Sebagai Upaya Meningkatkan Kualitas Pelayanan. Journal Of Health Studies. Https://Doi.Org/10.31101/Jhes.186

Samsirin. (2015). Konsep Mutu Dan Kepuasan Pelanggan Dalam Pendidikan Islam. Jurnal AtTa'dib.

Shaylide, I. S. (2014). Pengaruh Mutu Layanan Akademik Dan Biaya Pendidikan Terhadap Kepuasan Mahasiswa. Jurnal Administrasi Pendidikan Upi. Https://Doi.Org/10.17509/Jap.V21i2.6671

Sumarsono, R. B. (2015). Profesionalitas Kepala Sekolah \& Jaminan Mutu Pendidikan. In Tersedia Secara Online Di: Http://Ap. Fip. Um. Ac. Id

Tjiptono, F. (2004). Prinsip-Prinsip Total Quality Service. In Book.

Ushansyah. (2017). Pentingnya Administrasi Sekolah Untuk Kemajuan Pendidikan. Ittihad Jurnal Kopertais Wilayah Xi Kalimantan. 